\title{
Epstein-Barr virus as a marker of biological aggressiveness in breast cancer
}

\author{
C Mazouni", 1,2,6, F Fina', ${ }^{1,6}$, S Romain', L Ouafik ${ }^{3}$, P Bonnier ${ }^{4}$, J-M Brandone ${ }^{5}$ and P-M Martin' \\ 'Laboratoire de transfert d'oncologie biologique, Assistance Publique - Hôpitaux de Marseille, Faculté de Médecine Nord, Marseille, France; \\ ${ }^{2}$ Département de chirurgie générale, Institut Gustave Roussy, I I 4 rue Edouard Vaillant, Villejuif 94805, France; ${ }^{3}$ UMR 91 I CRO2: Centre de Recherche \\ en Oncologie biologique et Oncopharmacologie, Marseille F-13344. France; ${ }^{4}$ Département d'oncologie chirurgicale mammaire et gynécologique, \\ clinique Beauregard, Marseille, France; ${ }^{5}$ Départment de chirurgie gynécologique, clinique Bouchard, Marseille, France
}

PURPOSE: Although a potential role of the Epstein-Barr virus (EBV) in the pathogenesis of breast cancer (BC) has been underlined, results remain conflicting. Particularly, the impact of EBV infection on biological markers of $B C$ has received little investigation. METHODS: In this study, we established the frequency of EBV-infected BC using real-time quantitative PCR (RT-PCR) in I96 BC specimens. Biological and pathological characteristics according to EBV status were evaluated.

RESULTS: EBV DNA was present in 65 of the 196 (33.2\%) cases studied. EBV-positive BCs tended to be tumours with a more aggressive phenotype, more frequently oestrogen receptor negative $(P=0.05)$ and with high histological grade $(P=0.0 \mathrm{I})$. Overexpression of thymidine kinase activity was higher in EBV-infected BC $(P=0.007)$. The presence of EBV was weakly associated with HER2 gene amplification $(P=0.08)$.

CONCLUSION: Our study provides evidence for EBV-associated BC undergoing distinct carcinogenic processes, with more aggressive features.

British Journal of Cancer (20I I) I 04, 332-337. doi:I0.1038/sj.bjc.6606048 www.bjcancer.com

Published online 21 December 2010

(c) 20II Cancer Research UK

Keywords: breast cancer; Epstein-Barr virus; HER2; real-time quantitative PCR; thymidine kinase

A viral aetiology is one recently evocated theory behind the physiopathology of breast cancer (BC) (Glaser et al, 2004; de Villiers et al, 2005; zur Hausen, 2009). Even though, the mechanistic aspects of cancer induction by infectious agents sound multiples, that is, immunosuppressive, linked to animal-human transmission, direct or indirect oncogenic, there are epidemiological evidences of pathogens involvement in human cancer (zur Hausen, 2009).

Among the putative viruses observed in $\mathrm{BC}$ tissue, the presence of the Epstein-Barr virus (EBV), a $\gamma$-herpes virus, has been reported in a number of studies (Bonnet et al, 1999; Fina et al, 2001; Glaser et al, 2004). The implication of EBV in carcinogenesis associated with other cancers, such as Burkitt's lymphoma, undifferentiated nasopharyngeal carcinoma, as well as Hodgkin's disease, has been well documented (zur Hausen, 1991).

However, the presence and implication of EBV in BC remains controversial. The use of conventional technical approaches (in situ hybridisation, immunochemistry and standard PCR) for its detection may explain the conflicting results. Some groups have failed to detect EBV (Chang et al, 1992; Gaffey et al, 1993; Lespagnard et al, 1995; Chu et al, 1998; Glaser et al, 1998; Dadmanesh et al, 2001; Deshpande et al, 2002; Herrmann and Niedobitek, 2003; Perrigoue et al, 2005), whereas results from others show discrepancy and depended on the methodology used.

*Correspondence: Dr C Mazouni; E-mail: chafika.mazouni@igr.fr

${ }^{6}$ These authors contributed equally to this work.

Revised 12 October 2010; accepted 16 November 2010; published online 2I December 2010
For instance, although Murray et al (2003)could detect EBV nuclear antigen-1 by immunochemistry using 2B4-1 monoclonal antibody, they failed to detect the EBV genome by quantitative PCR. The reasons behind these apparently conflicting results remain to be clarified; however, technical limitations of the assays, dissimilarities in the archival materials and heterogeneity among cluster cells contaminated by the EBV genome may be same. Moreover, EBV positivity has been linked to the presence of latently infected lymphocytes in the tumours (Horiuchi et al, 1994; Brink et al, 2000) thus, questioning the role of EBV in BC (Chu et al, 2001). However, in accordance with other groups (Labrecque et al, 1995; Luqmani and Shousha, 1995; Bonnet et al, 1999; Chu et al, 2001; Huang et al, 2003; Preciado et al, 2005; Arbach et al, 2006; Perkins et al, 2006; Tsai et al, 2007), we have shown the presence of $\mathrm{EBV}$ genetic information in a subset of $\mathrm{BC}$ tissue with a specific localisation in the epithelial malignant cells (Fina et al, 2001).

Currently, real-time PCR (RT-PCR is increasingly being used for both research and clinical applications. For BC in particular, the detection of HER2 gene amplification has been validated by comparison with conventional methods, such as FISH (Lamy et al, 2006). Analysis using RT - PCR might also help to clearly identify the presence of EBV in BC. However, the use of whole tissue can result in the risk of contamination and this risk has been corrected with the introduction of laser-assisted microdissection (Fina et al, 2001). In studies on formalin-fixed sections, micro- and macrodissected breast tumours have been tested for the presence of multiple regions of the EBV genome with few actually uncovering the viral sequence (McCall et al, 2001; Thorne et al, 2005). Interestingly, by in situ hybridisation using a (35)S-labelled 
riboprobe for Epstein-Barr encoded RNA 1 and a laser capture microdissection on frozen samples, combined with quantitative PCR (Q-PCR), we showed that EBV localisation was restricted to certain tumour epithelial cell clusters (Fina et al, 2001). In accordance with our findings, Arbach et al (2006) observed that viral load is variable between tumours and is heterogeneously distributed among morphologically identical tumour cells, some clusters containing high genome numbers compared with others negative for EBV genome within the same specimen.

In the present study, we hypothesised that EBV-infected BC cells might behave differently in comparison to those negative for EBV. In order to test this, we sought to (i) measure the frequency of EBV positivity using $\mathrm{RT}-\mathrm{PCR}$ and (ii) to compare the biological phenotype of EBV-negative and EBV-positive tumours.

\section{MATERIALS AND METHODS}

\section{Patients}

This study involved 196 primary invasive breast carcinomas, with clinical and pathological characteristics as outlined in Table 1.

Table I Frequency of EBV positivity according to patient and tumour characteristics

\begin{tabular}{|c|c|c|c|c|}
\hline Characteristics & $n$ & $\begin{array}{c}\mathrm{EBV}+(\%) \\
(n=65)\end{array}$ & $\begin{array}{c}E B V-(\%) \\
(n=131)\end{array}$ & $P$-value \\
\hline All & 196 & 33.2 & 66.8 & \\
\hline \multicolumn{5}{|l|}{ Age (years) } \\
\hline$<50$ & 54 & $17(31.5)$ & $37(68.5)$ & NS \\
\hline$\geqslant 50$ & 142 & $34(33.8)$ & $63(66.2)$ & \\
\hline \multicolumn{5}{|l|}{ Tumour size ( $p T)$} \\
\hline$<2 \mathrm{~cm}$ & 99 & $31(31.3)$ & $68(68.7)$ & NS \\
\hline$>2 \mathrm{~cm}$ & 97 & $34(35.0)$ & $63(65.0)$ & \\
\hline \multicolumn{5}{|l|}{ Nodal status (pN) } \\
\hline $\mathrm{N}-$ & 120 & 30.0 & 70.0 & NS \\
\hline $\mathrm{N}+$ & 76 & 38.2 & 61.8 & \\
\hline \multicolumn{5}{|l|}{ Histological grade } \\
\hline । & 37 & $6(16.2)$ & 31 (83.8) & 0.01 \\
\hline$\|$ & 103 & $33(32.0)$ & $70(68.0)$ & \\
\hline III & 56 & $26(46.4)$ & $30(53.6)$ & \\
\hline \multicolumn{5}{|l|}{$E R$} \\
\hline Negative & 44 & $20(45.4)$ & $107(54.6)$ & 0.05 \\
\hline Positive & 152 & $45(29.6)$ & $45(70.4)$ & \\
\hline \multicolumn{5}{|l|}{$P R$} \\
\hline Negative & 62 & $23(37.1)$ & $39(62.9)$ & NS \\
\hline Positive & 134 & $42(31.3)$ & $92(68.7)$ & \\
\hline \multicolumn{5}{|l|}{ UPA } \\
\hline Low & 147 & $14(34.7)$ & $35(65.3)$ & NS \\
\hline High & 49 & $51(28.6)$ & $96(71.4)$ & \\
\hline \multicolumn{5}{|l|}{ PAI-I } \\
\hline Low & 147 & $48(32.6)$ & $99(67.4)$ & NS \\
\hline High & 49 & $17(34.7)$ & $32(65.3)$ & \\
\hline \multicolumn{5}{|l|}{ TK } \\
\hline Low & 147 & $24(27.9)$ & $25(72.1)$ & 0.007 \\
\hline High & 49 & $41(49.0)$ & $106(51.0)$ & \\
\hline HER2 amplification & & 14 & 16 & 0.13 \\
\hline
\end{tabular}

Abbreviations: $\%-, \%+=$ percentage of tumours negative and positive for $E B V$, respectively; $E B V=$ Epstein-Barr virus; $E R=$ oestrogen receptor; $N S=$ not significant; PAI-I = plasminogen activator inhibitor I; PR= progesterone receptor; $\mathrm{TK}=$ thymidine kinase; UPA $=$ urokinase plasminogen activator.
Patients were consecutively recruited in Marseille France, between May 1996 and December 1998. Tumours were graded according to the Scarff Bloom and Richardson classification (Bloom and Richardson, 1957). Axillary lymph node status was assessed by histological examination. The local Medical Ethics Committee (IRB) approved this laboratory study on stored specimens.

Tissue specimens All tumour samples were histologically examined by a pathologist at the time of initial surgery and stored in liquid nitrogen. Frozen tissue $(100 \mathrm{mg})$ was pulverised with a micro-dismembrator and the frozen powder subsequently used for DNA extraction (Sambrook et al, 1982). Cytosols were prepared using a Tris buffer $(10 \mathrm{~mm}$ Tris- $\mathrm{HCl}, 1.5 \mathrm{~mm}$ EDTA, $10 \mathrm{~mm}$ Na2MoO4, 0.5 mm dithiothreitol, $10 \%$ glycerol, $\mathrm{pH}$ 7.4).

Q-PCR analysis All Q-PCR reactions were performed on an ABI Prism 7700 sequence detection apparatus (Perkin-Elmer Corp., Foster City, CA, USA). The 5'-exonuclease (TaqMan) assay was used. Measurements were performed in duplicates. Levels of HER2 expression were normalised to those of the somatostatin receptor type II gene SSTR2 localised on chromosome 17 (q24) and to the glyceraldehyde-3-phosphate dehydrogenase gene GAPDH localised on chromosome 12 (p13). Levels of the BamHIC sub-region of the EBV genome were also normalised to GAPDH. After normalisation to GAPDH, the between-run CVs for BamHIC and HER2 internal controls (four series) were less than $10 \%$.

\section{Q-PCR analysis of HER2 gene}

The Q-PCR reaction conditions used have already been published (Lamy et al, 2006). The calibration curve was prepared from normal human genomic DNA (Roche Molecular Biochemicals, Meylan, France). Data were expressed as the HER2/GAPDH and HER2/SSTR2 relative copy number ratio. The human SKBR3 and A431 cell lines, known to, respectively, display HER2 amplification or not, were used as controls.

\section{Q-PCR analysis of the EBV genome}

The Q-PCR analysis of the EBV genome was performed as previously described (Fina et al, 2001). Briefly, primers for BamHIC were: sense, 5'-AAA-CAG-GAC-AGC-CGT-TGC-C-3' (6935-6953); antisense, 5'-AAG-CCT-CTC-TTC-TCC-TTC-CCC-3' (7036-7016) and the probe was 5'-FAM-TTT-CGG-ACA-CACCGC-CAA-CGC-T-TAMRA-3' (6961-6983). The cycling conditions for both BamHICs were as follows: $95^{\circ} \mathrm{C}$ for $15 \mathrm{~min}$; 45 cycles of $94^{\circ} \mathrm{C}$ for $20 \mathrm{~s}$, and $55^{\circ} \mathrm{C}$ for $20 \mathrm{~s}$. Amplification was performed in a $50-\mu \mathrm{l}$ reaction volume with a buffer consisting of $10 \mathrm{mmoll}^{-1}$ Tris-HCl (pH 8.3; $25^{\circ} \mathrm{C}$ ), $50 \mathrm{mmoll}^{-1} \mathrm{KCl}, 10 \mathrm{mmoll}^{-1}$ ethylenediamine tetraacetate and $5 \mathrm{mmoll}^{-1} \mathrm{MgCl} 2$ in the presence of $200 \mu \mathrm{moll}^{-1}$ deoxy(d)-ATP, dCTP and dGTP, $400 \mu \mathrm{moll}^{-1} \mathrm{dUTP}$, $200 \mathrm{nmoll}^{-1}$ of each primer, $200 \mathrm{nmoll}^{-1}$ probe, $1 \mathrm{U}$ Amp Erase UNG (Perkin-Elmer Corp.), and 1.25 U AmpliTaq Gold polymerase (Perkin-Elmer Corp.). To quantify the EBV genome load in the tissues, genomic DNA prepared from the Raji cell line, containing 50 integrated EBV copies per cell was used. Serial dilutions of DNA were prepared from $1 \mathrm{ng}$ to $0.1 \mathrm{pg}$ equivalent to $15000-1.5$ copies of EBV genome, respectively. Absolute quantification of the BamHIC standard curve involved comparison against normal human genomic DNA (Roche Molecular Biochemicals). The calibration curve for GAPDH was directly prepared from normal human genomic DNA. BamHIC data were expressed as the number of BamHIC copies per $100 \mathrm{ng}$ GAPDH. Normal human genomic DNA and controls lacking DNA always remained negative in the BamHIC Q-PCR analyses.

Biochemical assays Oestrogen receptors and progesterone receptors (PRs) (EIA, Abbott Laboratories, Chicago, IL, USA), as well as 
urokinase plasminogen activator (UPA) and plasminogen activator inhibitor type 1 (PAI-1) (UPA Imubind no 894 and PAI-1 Immubind no 821, both from American Diagnostica, Greenwich, CT, USA) were measured with enzyme immunoassays. Thymidine kinase (TK) activity was determined by a radioenzymatic phosphorylation assay (TK-REA, Sangtec Medical, Bromma, Sweden) optimised to detect the fetal TK1 isoenzyme, as previously described (Romain et al, 1994). Quality control was assured by frequent testing with internal controls. The EORTC standards were also used for oestrogen receptor and PR (Geurts-Moespot et al, 2000).

Statistical analysis Associations between categorical variables were tested by the $\chi^{2}$-test. Relationships between categorical and continuous variables were examined using the Mann-Whitney test, or in the case of more than two ordered categories, by the Kruskal-Wallis test. A $P$-value of $<0.05$ was considered significant. The HER2 gene was considered amplified when the HER2/GAPDH relative copy number was $\geqslant 2.0$. A threshold value of 4.0 was used to define a strong HER2 amplification. Samples with receptor content $\geqslant 20 \mathrm{fmol} \mathrm{mg}^{-1}$ protein were classified as oestrogen receptor or PR positive. Cut-offs corresponding to the seventyfifth percentiles in the distributions were used to dichotomise UPA, PAI-1 (Bouchet et al, 1999) and TK (Romain et al, 1995, $2000,2001)$ as previously recommended.

\section{RESULTS}

\section{Patient characteristics}

The demographics of the studied patients are reported in Table 1. The tumours had a diameter of more than $2 \mathrm{~cm}$ in 97 patients (49.5\%). In all, 76 patients $(38.8 \%)$ had positive axillary lymph nodes. The histological differentiation was determined as grade 3 in 56 tumours $(28.6 \%)$.

HER 2 gene amplification was detected in $15.3 \%(n=30)$ of the analysed BCs, with the HER2/GAPDH ratio for amplified cases ranging from 2.0-22.1 (median 4.5). Among the HER2-amplified tumours, $43.3 \%(n=13)$ showed moderate HER2 amplification (HER2/GAPDH ratio $2.0-4.0)$ and $56.7 \%(n=17)$ a strong amplification (HER2/GAPDH ratio $\geqslant 4.0)$.

\section{Q-PCR analysis of the EBV genome}

To ensure that the presence of EBV was related to epithelial cells, as previously described (Fina et al, 2001). Tissue sections were microdissected with a PixCell II LCM system (Arcturus Engineering, Mountain View, CA, USA). For each tumour analysed, several epithelial areas (approximatively $5 \times 10^{3}$ cells) were independently captured; stromal areas without infiltrating malignant epithelial cells were pooled to provide a sufficient number of GAPDH copies. Cell populations were estimated to be homogeneous as determined by microscopic visualisation. DNA from laser-captured cells was extracted and subsequently used for Q-PCR.

The presence of the BamHIC sub-region of the EBV genome was used to define EBV positivity. EBV was detected in $65(33.2 \%)$ of the 196 investigated BCs. Among the positive tumours, the load of EBV genome varied from 0.08 to $810.8 \mathrm{BamHIC}$ copies per $100 \mathrm{ng}$ GAPDH (median 1.4). Fibrocystic diseases $(n=3)$, fibroadenomas $(n=6)$, phyllode tumours $(n=4)$ and normal mammary tissue obtained from mammoplasty $(n=2)$ were also analysed. They were all found to be negative, with the exception of one phyllode tumour (0.43 BamHIC copies per $100 \mathrm{ng}$ GAPDH).

\section{Detection of the EBV genome and patient characteristics}

Table 1 shows the frequency of the EBV genome according to the characteristics of the patient and tumour.
Tumour positive for EBV presented markers of proliferation. Thus, the proportion of EBV-positive samples was significantly higher among the high-grade tumours $(16.2 \%$ for grade I, $32.0 \%$ for grade II and $46.4 \%$ for grade III, $P=0.01)$. EBV-positive samples were more frequent among those of ER-negative (45.4\%) compared with ER-positive tumours (29.6\%) $(P=0.05)$. Among the tumours with high TK, $49.0 \%$ displayed the EBV genome compared with $27.9 \%$ of those with low TK $(P=0.007)$. In contrast, no significant link was observed between the detection of the EBV genome and age at diagnosis, tumour size, lymph node involvement, PR, UPA or PAI-1 status.

To quantitatively assess the relation between the EBV presence and pathological markers, we have studied the load of EBV genome. We confirmed that BamHIC copy numbers were higher among high-grade tumours $(P=0.006)$ and between those ER-negative $(P=0.01)$ and high TK value $(P=0.009)$. Other relationships were not significant (Table 2 ).

\section{Detection of the EBV genome and amplification of HER2}

A weak association was observed between EBV genome presence and HER2 amplification. Subgroups with EBV - HER2 - $(n=115)$

Table 2 Mean EBV load (BamHIC copies) according to biological characteristics

\begin{tabular}{|c|c|c|}
\hline Characteristics & $\begin{array}{l}\text { Mean EBV load } \\
\text { (BamHIC copies per } \\
\text { I00 ng GAPDH) }\end{array}$ & $P$-value \\
\hline \multicolumn{3}{|l|}{ Age (years) } \\
\hline$<50$ & 0.79 & 0.42 \\
\hline$\geqslant 50$ & 7.84 & \\
\hline \multicolumn{3}{|l|}{ Tumour size (pT) } \\
\hline$<2 \mathrm{~cm}$ & 1.28 & 0.70 \\
\hline$\geqslant 2 \mathrm{~cm}$ & 10.60 & \\
\hline \multicolumn{3}{|l|}{ Nodal status (pN) } \\
\hline $\mathrm{N}-$ & 1.40 & 0.34 \\
\hline $\mathrm{N}+$ & 13 & \\
\hline \multicolumn{3}{|l|}{ Histological grade } \\
\hline I & 0.32 & 0.006 \\
\hline$\|$ & 2.58 & \\
\hline III & 15.7 & \\
\hline \multicolumn{3}{|l|}{$E R$} \\
\hline Negative & 1.64 & 0.01 \\
\hline Positive & 20.58 & \\
\hline \multicolumn{3}{|l|}{$P R$} \\
\hline Negative & 1.83 & 0.20 \\
\hline Positive & 14.67 & \\
\hline \multicolumn{3}{|l|}{ UPA } \\
\hline Low & 7.48 & 0.56 \\
\hline High & 1.12 & \\
\hline \multicolumn{3}{|l|}{ PAl-I } \\
\hline Low & 7.21 & 0.75 \\
\hline High & 1.93 & \\
\hline \multicolumn{3}{|l|}{ TK } \\
\hline Low & 1.87 & 0.009 \\
\hline High & 17.95 & \\
\hline No HER2 amplification & 27.9 & 0.10 \\
\hline HER2 amplification & 1.9 & \\
\hline
\end{tabular}

Abbreviations: $\mathrm{ER}=$ oestrogen receptor; $\mathrm{PAI}-\mathrm{I}$ = plasminogen activator inhibitor I; $\mathrm{PR}=$ progesterone receptor; $\mathrm{TK}=$ thymidine kinase; UPA = urokinase plasminogen activator. 
and EBV + HER2 $+(n=14)$ status represented $65.8 \%$ of the investigated patients $(P=0.09)$. When using the Mann-Whitney test, EBV-positive tumours showed the highest HER2 copy numbers though the difference did not reach significance $(P=0.08)$.

\section{DISCUSSION}

The aim of this study was to investigate the presence of EBV in BC, alongside possible associations with clinicopathological factors and biological tumour features that either mark the natural history of the disease or determine the therapeutic outcome. The analysed biological factors were selected on the basis of their high utility score in the tumour marker grading system (Isaacs et al, 2001), with evidence coming either from prospective trials or metaanalysis (ER, PR, HER2, UPA and PAI-1), or at least from large retrospective studies (TK).

The implication of EBV in the aetiology of $\mathrm{BC}$ has been addressed in other series, including a multicentric study carried out by our group (Fina et al, 2001). In accordance with tour analysis, the presence of EBV was showed to be restricted in the epithelial cells (Fawzy et al, 2008; Trabelsi et al, 2008; Joshi et al, 2009). EBV has been evocated along with other viruses, such as the papillomavirus (de Villiers et al, 2005; Kulka et al, 2008) or polyomavirus (Berebbi et al, 1990), as well as cytomegalovirus (Richardson et al, 2004). One of the controversies surrounding EBV as a causal agent in BC has been its potential coincidental presence as no virus-related physiopathological effects have emerged from pathological observations. However, one interesting epidemiological study provided some arguments in favour of a role and a potential explanation relating to the stage of mammary gland development. Indeed Yasui et al (2001) showed a correlation between the incidence of infectious mononucleosis and the risk of BC. Particularly, an increase in age corresponding to a later stage of mammary gland development at infectious mononucleosis onset seemed to increase the risk for $\mathrm{BC}$. We have also observed this potential link between the incidence of $\mathrm{BC}$ and hormonal status in one of our previous studies with the polyomavirus (Berebbi et al, 1990). Our evaluation of oncogenicity in nude mice showed that mammary tumour induction was oestrogen-dependent during a short period after polyomavirus injection. This sensitivity of the mammary gland to virus exposure corresponds to an oestradiolmediated modification of the target organ occurring during ductal development (Berebbi et al, 1990). After this developmental period, the mitogenic stimulus induced by hormones is no longer necessary. The influence of hormonal environment during the critical period of mammary gland development thus determines the future carcinogenesis process and the pool of hormoneresponsive epithelial cells (Nandi et al, 1995). However, the analysis of changes in EBV immunoglobulins (Ig) showed discrepant results; thus, although Cox et al (2010) failed to show an association with the risk of $\mathrm{BC}$ in Ig taken before and after the development of BC, in contrast Joshi et al (2009) observed no difference that mean anti-EBNA-1 IgG levels were significantly higher in $\mathrm{BC}$ patients as compared with benign breast disease.

The Q-PCR method has been used here to investigate EBV in a large series of BCs. Overall, $33.2 \%$ of the 196 frozen tumours analysed contained the BamHIC sub-region of the EBV genome that encodes the Epstein-Barr encoded RNAs. In our previous multi-centre study (Fina et al, 2001), the samples from our centre showed a positive ratio of $26.7 \%$ by standard PCR. The higher percentage of EBV-positive tumours observed in the present study may be related to the size of the tumours samples analysed, $(100 \mathrm{mg})$, and to the sensitivity of Q-PCR. Two other investigators have also found EBV by PCR in frozen tissues by PCR (Labrecque et al, 1995; Bonnet et al, 1999). The absence of detection
(Gaffey et al, 1993; Lespagnard et al, 1995) or the low detection rate even by RT - PCR (McCall et al, 2001) that has elsewhere been reported elsewhere could be due to result from the use of fixed tissues. Indeed, it has been demonstrated that fixation generates both PCR-inhibitory components (Satoh et al, 1998; Kösel et al, 2001; kalkan et al, 2005) and sequence alterations (Williams et al, 1999; Amarante and Watanabe, 2009). Inhibition of the viral DNA PCR amplification was most likely the case for the study of McCall and colleagues (McCall et al, 2001). Kalkan et al (2005) and Thorne et al (2005) detected EBV genome in epithelial and also in normal cells. In these studies, low amounts of template DNA was probably used as the tissues were microdissected and DNA amplificability was controlled by HER2 detection. In our BC samples, the loads of EBV genetic information (BamHIC per $100 \mathrm{ng}$ DNA) ranged far below the range of HER2 values (HER2/GAPDH copy number). The high heterogeneity in EBV detection that has been shown within individual tumours also needs to be considered (Fina et al, 2001).

In this study, we observed a difference in clinical and biological profiles between EBV-positive and EBV-negative cancers. In accordance with Tsai et al (2007) though in contrast toMurray et al (2003), we found no correlation between the presence of EBV and nodal status. Here, we have investigated markers of epithelial cells (ER, PR, grade and TK), whereas UPA and PAI-1, which are markers of stromal-epithelial interactions, associated with tumoural invasion process. In line with this result, no association was observed with the biological factors (UPA or PAI-1) related to tumour invasion. However, we did confirm that the proportion of EBV-positive samples is higher among the high-grade and the ER-negative cancers (Bonnet et al, 1999; Murray et al, 2003). These latter biological factors related to differentiation status (Rose et al, 1985; McGuire et al, 1986; Murray et al, 2003) were strongly associated with EBNA-1 as detected by immunostaining. Altogether these results confirm the epithelial presence of EBV as only correlations with epithelial markers were observed and not with the markers of stromal compartment. Interestingly, we showed a positive association between the presence of EBV and high cytosolic TK enzyme activity. High expression of this enzyme involved in the DNA synthesis salvage pathway has previously been associated with large tumour size, high histological grade and steroid hormone receptor negativity (Romain et al, 2000). The TK encoded by the EBV is localised in the centrosome, a localisation observed in diverse cell types whether the protein is expressed independently or in the context of lytic EBV infection (Gill et al, 2007). Although EBV TK is an early gene, it was nevertheless found to be transcribed with a significant delay compared with other early-class RNAs (Yuan et al, 2006). The commercial assay used to access TK activity has been optimised for the TK1 isoenzyme. The link between EBV and TK supports the notion that EBV is associated with fast-growing tumours. It agrees with data suggesting that DNA tumour viruses suppress the transcriptional downregulation of TK activity during the eukaryotic cell cycle (Hengstschläger et $a l, 1994$ ), and that nasopharyngeal carcinomas with detectable EBV LMP1 protein grow faster than the nonexpressing ones (Hu et al, 1995). Concerning the link between EBV positive tumours and high TK expression, we sequenced mRNA and found that the expression of $T K$ gene found in EBV-positive tumours is of human origin, not viral (data not shown). This human TK differs from the one deposited by Bradshaw and Deininger in the Genbank database (Gilles et al, 2003). In a previous study, Huang et al (2003), detected the EBV-encoded lytic transactivator protein ZTA in 7 out of 10 BCs. Interestingly, ZTA specifically binds the CCAAT motif $(\mathrm{C} / \mathrm{EBP} \alpha$, enhancer binding protein $\alpha$ ) of the TK1 human gene promoter, which suggests a functional role in the activation of TK1 transcription.

In this study, the presence of EBV was only weakly associated with HER2 amplification. This result, together with the fact that 
EBV and HER2 correlate differently with other tumour features, suggests that the viral infection and the gene amplification occur at different times during BC progression. In BCs, both EBV (Bonnet et al, 1999) and HER2 (Révillion et al, 1998; Yamauchi et al, 2001) have been associated with a lack of oestrogen receptors.

In conclusion, we confirmed the presence of EBV in one third of BC. Moreover, EBV-positive tumours presented with a more aggressive phenotype that could be useful when considering potential therapeutic targets. In particular, the high TK levels could confer resistance to chemotherapy.

\section{ACKNOWLEDGEMENTS}

This work was supported by a grant from the Assistance Publique de Marseille (AORC 1998; UF 2843). A Durand, and M Soullière are acknowledged for their skilful technical assistance.

\section{REFERENCES}

Amarante MK, Watanabe MA (2009) The possible involvement of virus in breast cancer. J Cancer Res Clin Oncol 135: 329-337

Arbach H, Viglasky V, Lefeu F, Guinebretière JM, Ramirez V, Bride N, Boualaga N, Bauchet T, Peyrat JP, Mathieu MC, Mourah S, Podgorniak MP, Seignerin JM, Takada K, Joab I (2006) Epstein-Barr virus (EBV) genome and expression in breast cancer tissue: effect of EBV infection of breast cancer cells on resistance to paclitaxel (Taxol). J Virol 80: 845-853

Berebbi M, Martin PM, Berthois Y, Bernard AM, Blangy D (1990) Estradiol dependence of the specific mammary tissue targeting of polyoma virus oncogenicity in nude mice. Oncogene 5: 505-509

Bloom HJ, Richardson WW (1957) Histological grading and prognosis in breast cancer; a study of 1409 cases of which 359 have been followed for 15 years. Br J Cancer 11: 359-377

Bonnet M, Guinebretiere JM, Kremmer E, Grunewald V, Benhamou E, Contesso G, Joab I (1999) Detection of Epstein-Barr virus in invasive breast cancers. J Natl Cancer Inst 91: 1376-1381

Bouchet C, Hacène K, Martin PM, Becette V, Tubiana-Hulin M, Lasry S, Oglobine J, Spyratos F (1999) Dissemination risk index based on plasminogen activator system components in primary breast cancer. J Clin Oncol 17: 3048-3057

Brink AA, van Den Brule AJ, van Diest P, Meijer CJ (2000) Re: detection of Epstein Barr virus in invasive breast cancers. J Natl Cancer Inst 92: $655-656$

Chang KL, Chen YY, Shibata D, Weiss LM (1992) Description of an in situ hybridization methodology for detection of Epstein-Barr virus RNA in paraffin-embedded tissues, with a survey of normal and neoplastic tissues. Diagn Mol Pathol 1: 246-255

Chu JS, Chen CC, Chang KJ (1998) In situ detection of Epstein-Barr virus in breast cancer. Cancer Lett 124: $53-57$

Chu PG, Chang KL, Chen YY, Chen WG, Weiss LM (2001) No significant association of Epstein-Barr virus infection with invasive breast carcinoma. Am J Pathol 159: 571-578

Cox B, Richardson A, Graham P, Gislefoss RE, Jellum E, Rollag H (2010) Breast cancer, cytomegalovirus and Epstein-Barr virus: a nested case-control study. Br J Cancer 102: 1665-1669

Dadmanesh F, Peterse JL, Sapino A, Fonelli A, Eusebi V (2001) Lymphoepithelioma-like carcinoma of the breast: lack of evidence of Epstein-Barr virus infection. Histopathology 38: 54-61

de Villiers EM, Sandstrom RE, zur Hausen H, Buck CE (2005) Presence of papillomavirus sequences in condylomatous lesions of the mamillae and in invasive carcinoma of the breast. Breast Cancer Res 7: R1-11

Deshpande CG, Badve S, Kidwai N, Longnecker R (2002) Lack of expression of the Epstein-Barr Virus (EBV) gene products, EBERs, EBNA1, LMP1, and LMP2A, in breast cancer cells. Lab Invest 82: 1193-1199

Fawzy S, Sallam M, Awad NM (2008) Detection of Epstein-Barr virus in breast carcinoma in Egyptian women. Clin Biochem 41: 486-492

Fina F, Romain S, Ouafik L, Palmari J, Ben Ayed F, Benharkat S, Bonnier P, Spyratos F, Foekens JA, Rose C, Buisson M, Gérard H, Reymond MO, Seigneurin JM, Martin PM (2001) Frequency and genome load of Epstein-Barr virus in 509 breast cancers from different geographical areas. Br J Cancer 84: 783-790

Gaffey MJ, Frierson Jr HF, Mills SE, Boyd JC, Zarbo RJ, Simpson JF, Gross LK, Weiss LM (1993) Medullary carcinoma of the breast. Identification of lymphocyte subpopulations and their significance. Mod Pathol 6: $721-728$

Geurts-Moespot J, Leake R, Benraad TJ, Sweep CG (2000) Twenty years of experience with the steroid receptor external quality assessment program - the paradigm for tumour biomarker EQA studies. On behalf of the EORTC Receptor and Biomarker Study Group. Int J Oncol 17: 13-22
Gill MB, Kutok JL, Fingeroth JD (2007) Epstein-Barr virus thymidine kinase is a centrosomal resident precisely localized to the periphery of centrioles. J Virol 81: 6523-6535

Gilles SI, Romain S, Casellas P, Ouafik L, Fina F, Combes T, Vuaroquaux V, Seitz JF, Bonnier P, Galiègue S, Carayon P, Martin PM (2003) Mutation analysis in the coding sequence of thymidine kinase 1 in breast and colorectal cancer. Int J Biol Markers 18: 1-6

Glaser SL, Ambinder RF, DiGiuseppe JA, Horn-Ross PL, Hsu JL (1998) Absence of Epstein-Barr virus EBER-1 transcripts in an epidemiologically diverse group of breast cancers. Int J Cancer 75: 555-558

Glaser SL, Hsu JL, Gulley ML (2004) Epstein-Barr virus and breast cancer: state of the evidence for viral carcinogenesis. Cancer Epidemiol Biomarkers Prev 13: $688-697$

Hengstschläger M, Knöfler M, Müllner EW, Ogris E, Wintersberger E, Wawra E (1994) Different regulation of thymidine kinase during the cell cycle of normal versus DNA tumor virus-transformed cells. J Biol Chem 269: $13836-13842$

Herrmann K, Niedobitek G (2003) Lack of evidence for an association of Epstein-Barr virus infection with breast carcinoma. Breast Cancer Res 5: R13-R17

Horiuchi K, Mishima K, Ohsawa M, Aozasa K (1994) Carcinoma of stomach and breast with lymphoid stroma: localisation of Epstein-Barr virus. J Clin Pathol 47: 538-540

Hu LF, Chen F, Zhen QF, Zhang YW, Luo Y, Zheng X, Winberg G, Ernberg I, Klein G (1995) Differences in the growth pattern and clinical course of EBV-LMP1 expressing and non-expressing nasopharyngeal carcinomas. Eur J Cancer 31A: 658-660

Huang J, Chen H, Hutt-Fletcher L, Ambinder RF, Hayward SD (2003) Lytic viralreplication as a contributor to the detection of Epstein-Barr virus in breast cancer. J Virol 77: 13267-13274

Isaacs C, Stearns V, Hayes DF (2001) New prognostic factors for breast cancer recurrence. Semin Oncol 28: 53-67

Joshi D, Quadri M, Gangane N, Joshi R, Gangane N (2009) Association of Epstein Barr virus infection (EBV) with breast cancer in rural Indian women. PLoS One 4: e8180

Kalkan A, Ozdarendeli A, Bulut Y, Yekeler H, Cobanoglu B, Doymaz MZ (2005) Investigation of Epstein-Barr virus DNA in formalin-fixed and paraffin- embedded breast cancer tissues. Med Princ Pract 14: $268-271$

Kulka J, Kovalszky I, Svastics E, Berta M, Füle T (2008) Lymphoepithelioma-like carcinoma of the breast: not Epstein-Barr virus-, but human papilloma virus-positive. Hum Pathol 39: 298-301

Kösel S, Grasbon-Frodl EM, Arima K, Chimelli L, Hahn M, Hashizume Y, Hulette C, Ikeda K, Jacobsen PF, Jones M, Kobayashi M, Love S, Mizutani T, Rosemberg S, Sasaki A, Smith TW, Takahashi H, Vortmeyer AO, Graeber MB (2001) Inter-laboratory comparison of DNA preservation in archival paraffin-embedded human brain tissue from participating centres on four continents. Neurogenetics 3: $163-170$

Labrecque LG, Barnes DM, Fentiman IS, Griffin BE (1995) Epstein-Barr virus in epithelial cell tumors: a breast cancer study. Cancer Res 55: $39-45$

Lamy PJ, Nanni I, Fina F, Bibeau F, Romain S, Dussert C, Penault Llorca F, Grenier J, Ouafik LH, Martin PM (2006) Reliability and discriminant validity of HER2 gene quantification and chromosome 17 aneusomy analysis by real-time PCR in primary breast cancer. Int J Biol Markers 21: $20-29$

Lespagnard L, Cochaux P, Larsimont D, Degeyter M, Velu T, Heimann R (1995) Absence of Epstein-Barr virus in medullary carcinoma of the breast as demonstrated by immunophenotyping, in situ hybridization and polymerase chain reaction. Am J Clin Pathol 103: 449-452 
Luqmani Y, Shousha S (1995) Presence of Epstein-Barr virus in breast carcinoma. Int J Oncol 6: 899-903

McCall SA, Lichy JH, Bijwaard KE, Aguilera NS, Chu WS, Taubenberger JK (2001) Epstein-Barr virus detection in ductal carcinoma of the breast. J Natl Cancer Inst 93: 148-150

McGuire WL, Clark GM, Dressler LG, Owens MA (1986) Role of steroid hormone receptors as prognostic factors in primary breast cancer. NCI Monogr 1: 19-23

Murray PG, Lissauer D, Junying J, Davies G, Moore S, Bell A, Timms J, Rowlands D, McConkey C, Reynolds GM, Ghataura S, England D, Caroll R, Young LS (2003) Reactivity with a monoclonal antibody to Epstein-Barr virus (EBV) nuclear antigen 1 defines a subset of aggressive breast cancers in the absence of the EBV genome. Cancer Res 63: 2338-2343

Nandi S, Guzman RC, Yang J (1995) Hormones and mammary carcinogenesis in mice, rats, and humans: a unifying hypothesis. Proc Natl Acad Sci USA 92: 3650-3657

Perkins RS, Sahm K, Marando C, Dickson-Witmer D, Pahnke GR, Mitchell M, Petrelli NJ, Berkowitz IM, Soteropoulos P, Aris VM, Dunn SP, Krueger LJ (2006) Analysis of Epstein-Barr virus reservoirs in paired blood and breast cancer primary biopsy specimens by real time PCR. Breast Cancer Res 8: R70

Perrigoue JG, den Boon JA, Friedl A, Newton MA, Ahlquist P, Sugden B (2005) Lack of association between EBV and breast carcinoma. Cancer Epidemiol Biomarkers Prev 14: 809-814

Preciado MV, Chabay PA, De Matteo EN, Gonzalez P, Grinstein S, Actis A, Gass HD (2005) Epstein-Barr virus in breast carcinoma in Argentina. Arch Pathol Lab Med 129: 377 - 381

Révillion F, Bonneterre J, Peyrat JP (1998) ERBB2 oncogene in human breast cancer and its clinical significance. Eur J Cancer 34: $791-808$

Richardson AK, Cox B, McCredie MR, Dite GS, Chang JH, Gertig DM, Southey MC, Giles GG, Hopper JL (2004) Cytomegalovirus, Epstein-Barr virus and risk of breast cancer before age 40 years: a case-control study. Br J Cancer 90: 2149-2152

Romain S, Bendahl PO, Guirou O, Malmström P, Martin PM, Fernö M (2001) DNA-synthesizing enzymes in breast cancer (thymidine kinase, thymidylate synthaseand thymidylate kinase): association with flow cytometric S-phase fraction and relative prognostic importance in node-negative premenopausal patients. Int J Cancer 95: 56-61

Romain S, Christensen IJ, Chinot O, Balslev I, Rose C, Martin PM, Thorpe SM (1995) Prognostic value of cytosolic thymidine kinase activity as a marker of proliferation in breast cancer. Int J Cancer 61: 7-12

Romain S, Spyratos F, Descotes F, Daver A, Rostaing-Puissant B, Bougnoux P, Colonna M, Bolla M, Martin PM (2000) Prognostic of
DNA-synthesizing enzyme activities (thymidine kinase and thymidylate synthase) in 908 T1-T2, N0-N1, M0 breast cancers: a retrospective multicenter study. Int J Cancer 87: 860-868

Romain S, Spyratos F, Guirou O, Deytieux S, Chinot O, Martin PM (1994) Technical evaluation of thymidine kinase assay in cytosols from breast cancers. EORTC Receptor Study Group Report. Eur J Cancer 30A: $2163-2165$

Rose C, Thorpe SM, Andersen KW, Pedersen BV, Mouridsen HT, BlichertToft M, Rasmussen BB (1985) Beneficial effect of adjuvant tamoxifen therapy in primary breast cancer patients with high oestrogen receptor values. Lancet 1: 16-19

Sambrook J, Fritsch EF, Maniatis T (1982) Molecular cloning: a laboratory manual. Harbor Laboratory: Cold Spring

Satoh Y, Takasaka N, Hoshikawa Y, Osaki M, Ohfuji S, Ito H, Kaibara N, Kurata T, Sairenji T (1998) Pretreatment with restriction enzyme or bovine serum albumin for effective PCR amplification of Epstein-Barr virus DNA in DNA extracted from paraffin-embedded gastric carcinoma tissue. J Clin Microbiol 36: 3423-3425

Thorne LB, Ryan JL, Elmore SH, Glaser SL, Gulley ML (2005) Real-time PCR measures Epstein-Barr virus DNA in archival breast adenocarcinomas. Diagn Mol Pathol 14: 29-33

Trabelsi A, Rammeh S, Stita W, Mokni M, Mourou A, Korbi S (2008) Detection of Epstein-Barr virus in breast cancers with lymphoid stroma. Ann Biol Clin 66: 59-62

Tsai JH, Hsu CS, Tsai CH, Su JM, Liu YT, Cheng MH, Wei JC, Chen FL, Yang CC (2007) Relationship between viral factors, axillary lymph node status and survival in breast cancer. J Cancer Res Clin Oncol 133: $13-21$

Williams C, Pontén F, Moberg C, Söderkvist P, Uhlén M, Pontén J, Sitbon G, Lundeberg J (1999) A high frequency of sequence alterations is due to formalin fixation of archival specimens. Am J Pathol 155: 1467-1471

Yamauchi H, Stearns V, Hayes DF (2001) When is a tumor marker ready for prime time? A case study of c-erbB-2 as a predictive factor in breast cancer. J Clin Oncol 19: 2334-2356

Yasui Y, Potter JD, Stanford JL, Rossing MA, Winget MD, Bronner M, Daling J (2001) Breast cancer risk and 'delayed' primary Epstein-Barr virus infection. Cancer Epidemiol Biomarkers Prev 10: 9-16

Yuan J, Cahir-McFarland E, Zhao B, Kieff E (2006) Virus and cell RNAs expressed during Epstein-Barr virus replication. J Virol 80: $2548-2565$

zur Hausen H (1991) Viruses in human cancers. Science 254: 1167-1173

Zur Hausen H (2009) The search for infectious causes of human cancers: where and why. Virology 392: 1-10 